\title{
E-Banking in Emerging Economy: Empirical Evidence of Iran
}

\author{
Mahdi Salehi (Corresponding author) \\ Accounting and Management Department, Zanjan University, Iran \\ D.N. 1, Nagilo Alley, Emam Street, Hidaj City, Zanjan Province, Iran \\ Tel: 98-912-142-5323 E-mail: mahdi_salehi54@yahoo.com
}

\author{
Mehrdad Alipour \\ Management Department, Islamic Azad University, Zanjan Branch, Zanjan City, Iran
}

Tel: 98-912-740-0929 E-mail: mehrdadalipour@yahoo.com

\begin{abstract}
Now a day's due to emerging global economy, e-commerce and e-business have increasingly become a necessary component of business strategy and a strong catalyst for economic development. The integration of information and communications technology in business has revolutionized relationships within organizations and those between and among organizations and individuals. The new information technology is becoming an important factor in the future development of financial services industry, and especially banking industry. The results of this study shows that e-banking serves several advantages to Iranian banking sector, however, the study also shows that the Iranian customers have not enough knowledge regarding e-banking which is rendering by banking sector in Iran.
\end{abstract}

Keywords: Banking sector, E-banking, Iran

\section{Introduction}

Financial services industry has recently been open to historic transformation, it can call e-developments are emerging and advancing rapidly in all areas of financial intermediation and financial markets: e-finance, e-money, electronic banking (e-banking), e-brokering, e-insurance, e-exchanges, and even e-supervision. The new information technology (IT) is turning into the most important factor in the future development of banking, influencing banks' marketing and business strategies. In recent years, the adoption of e-banking began to occur quite extensively as a channel of distribution for financial services due to rapid advances in IT and intensive competitive banking markets. The driving forces behind the rapid transformation of banks are influential changes in the economic environment: innovations in information technology, innovations in financial products, liberalization and consolidation of financial markets, deregulation of financial inter-mediation etc. These and other factors make it complicated to design a bank's strategy, which process is threatened by unforeseen developments and changes in the economic environment and therefore, strategies must be flexible to adjust to these changes. The financial services market is continuing to change rapidly, which brings into question whether traditional banks, as they are now structured, will actually continue to exist by the end of the decade or even survive through the next five years. Competition has been increasing for some years within traditional financial centers, amongst the banks themselves. A significant challenge comes from international banks offering technology-based financial services across geographical boundaries and thereby competing with traditional banks for their best business within their own back yard.

Indeed, there is a growing concern that e-banking is not yielding the anticipated results, creating a gap between the actual returns and the proposed objectives and thereby losing a large amount of investment. This especially concerns the interaction with clients and thereby increased and more rapid access to new markets. This has thrown the spotlight onto the problem of change from one particular delivery channel to another. This is highly important since the implementation of e-banking may have radical implications on a bank's structures, business processes, products and services and value flows with clients and other parties.

A strong banking industry is important in every country and can have a significant affect in supporting economic development through efficient financial services. In Iran the role of the banking industry needs to change to keep up with the globalization movement, both at the procedural level and at the informational level. This change will include moving from traditional distribution channel banking to electronic distribution channel banking. Given the almost complete adoption of e-banking in developed countries, the reason for the lack of such adoption in developing countries like Iran is an important research that will be addressed by this paper. In other words, despite this growth of IT worldwide, Iranian banks continue to conduct most of their banking transactions using traditional methods. Understanding the reasons for the lack of such technological innovation in developing countries such as Iran will 
develop a fruitful research. The aim of the paper is to look at the emergence, advantages and acceptance of e-banking in Iran.

\section{Definition of e-banking}

E-banking is the newest delivery channel for banking services. Banks have used electronic channels for years to communicate and transact business with both domestic and international corporate customers. With the development of the Internet and the World Wide Web (WWW) in the latter half of the 1990s, banks are increasingly using electronic channels for receiving instructions and delivering their products and services to their customers. This form of banking is generally referred to as e-banking or Internet banking, although the range of products and services provided by banks over the electronic channel vary widely in content, capability and sophistication. E-banking is defined as the automated delivery of new and traditional banking products and services directly to customers through electronic, interactive communication channels. The definition of e-banking varies amongst researches partially because electronic banking refers to several types of services through which bank customers can request information and carry out most retail banking services via computer, television or mobile phone (Daniel, 1999; Mols, 1998; Sathye, 1999). Burr (1996), for example, describes it as an electronic connection between bank and customer in order to prepare, manage and control financial transactions. Electronic banking can also be defined as a variety of following platforms:

(a) Internet banking (or online banking), (b) telephone banking, (c) TV-based banking, (d) mobile phone banking, and e-banking (or offline banking).

As online Internet banking and mobile phone banking are the fastest developing areas, in the present paper the focus is mainly on the development and the future of these platforms.

E-banking includes the systems that enable financial institution customers, individuals or businesses, to access accounts, transact business, or obtain information on financial products and services through a public or private network, including the Internet or mobile phone. Customers access e-banking services using an intelligent electronic device, such as a personal computer (PC), personal digital assistant (PDA), automated teller machine (ATM), kiosk, or Touch Tone telephone. While some literature restricts the use of the term to internet banking (i.e. Daniel 1999), elsewhere the term is limited to retail banking (Aladwani 2001) or both retail and corporate banking (Simpson 2002). The common definition for e-banking, and the one used in this paper, comes from the Basel Committee Report on Banking Supervision $(1998,3)$, 'e-banking refers to the provision of retail and small value banking products and services through electronic channels. Such products and services can include deposit-taking, lending, account management, the provision of financial advice, electronic bill payment, and the provision of other electronic payment products and services such as electronic money.'

\section{E-banking benefits}

E-banking serves several benefits to any societies which are summarized as below:

\section{Benefits from the banks' point of view}

From the banks' view point, the first benefits for the banks offering e-banking services is better branding and better responsiveness to the market. Those banks that would offer such services would be perceived as leaders in technology implementation. Therefore, they would enjoy a better brand image.

The other benefits are possible to measure in monetary terms. The main goal of every company is to maximize profits for its owners and banks are not any exception. Automated e-banking services offer a perfect opportunity for maximizing profits.

According to a survey an estimated cost providing the routine business of a full service branch in USA is $\$ 1.07$ per transaction, as compared to 54 cents for telephone banking, 27 cents for ATM (Automatic Teller Machine) banking and 1.5 cents for Internet banking (Nathan 1999; Pyun et al., 2002).

\section{Benefits from the customers' point of view}

The main benefit from the bank customers' point of view is significant saving of time by the automation of banking services processing and introduction of an easy maintenance tools for managing customer's money. The main advantages of e-banking for corporate customers are as follows (Gurău, 2002). Reduced costs in accessing and using the banking services. According to their idea the main benefits of e-banking are as flow:

1) Increased comfort and timesaving - transactions can be made 24 hours a day, without requiring the physical interaction with the bank, without requiring the physical interaction with the bank.

2) Quick and continuous access to information. Corporations will have easier access to information as, they can check on multiple accounts at the click of a button.

3) Better cash management. E-banking facilities speed up cash cycle and increases efficiency of business processes as large variety of cash management instruments is available on Internet sites of banks. 
4) Private customers seek slightly different kind of benefits from e-banking. In the study on online banking drivers Aladwani (2001) has found, that providing faster, easier and more reliable services to customers were amongst the top drivers of e-banking development. The main benefits from e-banking for private customers are as follows (BankAway, 2001):

1) Reduced costs: This is in terms of the cost of availing and using the various banking products and services.

2) Convenience: All the banking transactions can be performed from the comfort of the home or office or from the place a customer wants to.

3) Speed. The response of the medium is very fast; therefore customers can actually wait till the last minute before concluding a fund transfer.

4) Funds management. Customers can download their history of different accounts and do a "what-if" analysis on their own PC before affecting any transaction on the web. This will lead to better funds management.

\section{Economical benefits}

The impact of the New Economy on the entire economic growth has been studied in several research projects. For example Pohjola (2002) shows, that the contribution of the use of information communication technology to growth of output in the Finnish market sector has increased from 0.3 percentage points in early 1990 s to 0.7 points in late 1990 s. However, unlike the US, there has been no acceleration in the trend rate of labor productivity in Finland.

According to the recent research conducted in Estonia (Aarma and Vensel, 2001), bank customers use bank office services on average 1.235 times per month, and wait in queue in bank office on average for 0.134 hours.

In nutshell, E-banking serves so many benefits not only to the bank it self, but also to the society at whole. Accordingly From bank's side, e-banking makes finance economically possible:

(1) Lower operational costs of banks

\section{Automated process}

. Accelerated credit decisions

. Lowered minimum loan size to be profitable

(2) Potentially lower margins

. Lower cost of entry

. Expanded financing reach

Increased transparency

(3) Expand reach through self-service

. Lower transaction cost

. Make some corporate services economically feasible for society

. Make anytime access to accounts and loan information possible

- From society perspective

E-banking business makes access to finance from banks attractive. Society have benefited from the development of Efinance and gradually stepped out of the informal sector. In particular, E- finance offers the following attractive benefits for society:

. Ease of use

. Lower costs of financing

. Convenience

. Time savings

. Operational efficiency

\section{History of banking in Iran}

La Porta et al., (2002) documents that government ownership of banks is pervasive worldwide. In 1995 state ownership in the banking industry around the world averaged about $41.6 \%$ percent $(38.5 \%$ if we exclude former socialist countries). Mayer (1990) shows that bank financing is the main source of outside financing in all countries. Yet despite the prevalence of government-owned banks in many countries, the prominent role of bank financing, and the importance of efficient financial markets for growth, there is very little evidence on how government ownership affects bank lending. 
Banking operations had been carried out in Iran by temples and princes before the advent of Achaemenid dynasty by government. In that period, trade boomed in the country, thus giving a boost to banking. Before a bank in its present form was established in the country, banking operations had been carried out in traditional forms in the form of money changing. Money changing began to decline with the establishment of New East Bank, an originally British owned bank in the country in 1850. Bank Sepah was the first bank to be established with Iranian capitals in 1925 under the name of Bank Pahlavi Qoshun, in order to handle the financial affairs of the military personnel and set up their retirement fund. The primary capital of the bank was 388,395 Tomans. In the spring of 1979, all Iranian banks were nationalized and banking laws changed with the approval of the new interest free Islamic banking regulations. Before a bank in its present form was established in Iran, banking operations had been carried out in traditional form, or in other words in the form of money changing. Simultaneous with promotion of trade and business in the country, more people chose money changing as their occupation.

Following a boost in trade and use of bank notes and coins in trade during the Parthian and Sassanian eras, exchange of coins and hard currencies began in the country. Some people also managed to specialize in determining the purity of coins. Bank notes and gold coins were first used in the country following the conquest of Lidi by Achaemenid king Darius in 516 B.C. At that time, a gold coin called Derick was minted as the Iranian currency. During the Parthian and Sassanian eras, both Iranian and foreign coins were used in trade in the country. However, with the advent of Islam in Iran, money changing and use of bank notes and coins in trade faced stagnation because the new religion forbade interest in dealing. In the course of Mongol rule over Iran, a bank note which was an imitation of Chinese bank notes was put in circulation. The bank notes, called Chav bore the picture and name of Keikhatu. On one side of the bank notes there was the following sentence: "Anybody who does not Besides Chav, other bank notes were used for a certain period of time in other Iranian cities and then got out of circulation. Before the printing of first bank notes by the Bank Shahanshahi (Imperial Bank), a kind of credit card called Bijak had been issued by money dealers. As mentioned before, money changing got out of fashion with the advent of Islam under which usury is strictly forbidden.

The New East Bank establishment 1850 and it was in fact the first banking institute in its present form established in Iran. It laid the foundation of banking operations in the country. It was a British bank whose headquarters was in London. The bank was established by the British without receiving any concession from the Iranian government. The New East Bank allowed individuals to open accounts, deposit their money with the bank and draw checks. It was at this time that people began to draw checks in their dealings. In order to compete with money dealers, the bank paid interest on the fixed deposits and current accounts of its clients. The head office of the bank in Tehran issued five 'qeran' bank notes in the form of drafts. According to a concession granted by the Iranian government to Baron Julius De Reuter in 1885, Bank Shahanshahi (Imperial Bank) was established. This bank purchased the properties and assets of the New East Bank, thus putting an end to the baking operations of the former. The activities of Bank Shahanshahi ranged from trade transactions, printing bank notes, and serving as the treasurer of the Iranian government at home and abroad in return for piecework wage. In return for receiving this concession, Reuter obliged to pay six percent of the annual net income of the bank, providing that the sum should not be less than 4,000 pounds, and 16 percent of incomes from other concessions to the Iranian government. The legal center of the bank was in London and it was subject to the British laws but its activities were centered in Tehran.

In 1209 (lunar hejira), the right of printing bank notes was purchased from Bank Shahanshahi for a sum of 200,000 pounds and ceded to the Bank Melli of Iran. Bank Shahanshahi continued its activities until 1948 when its name was changed into Bank of Britain in Iran and Middle East. The activities of the bank continued until 1952. In 1269 (1.h.), a Russian national by the name of Jacquet Polyakov, received a concession from the then government of Iran for establishment of Bank Esteqrazi for 75 year. Besides, banking and mortgage operations, the bank had an exclusive right of public auction. In 1898 the Tzarist government of Russia bought all shares of the bank for its political ends. Under a contract signed with Iran, the bank was transferred to the Iranian government in 1920. The bank continued its activities under the name of Bank Iran until 1933 when it was incorporated into the Bank Keshavarzi (Agriculture Bank).

Bank Sepah was the first bank to be established with Iranian capitals in 1925 under the name of Bank Pahlavi Qoshun, in order to handle the financial affairs of the military personnel and set up their retirement fund. With Bank Sepah opening its branches in major Iranian cities, the bank began carrying financial operations such as opening of current accounts and transfer of money across the country. The Iran-Russia Bank was formed by the government of the former Soviet Union in 1926 with an aim of facilitating trade exchanges between the two countries.

The headquarters of the bank was in Tehran with some branches being inaugurated in northern parts of the country. The bank dealt with financial affairs of institutes affiliated to the government of the former Soviet Union and trade exchanges between the two countries. The activities of this bank, which were subject to Iranian banking regulations, continued until 1979. In that year, this bank along with 27 other state-owned or private banks was nationalized under a decision approved by the Revolutionary Council of the Islamic Republic of Iran. 
The proposal to establish a national Iranian bank was first offered by a big money dealer to Qajar king Nasereddin Shah before the Constitutional Revolution. But the Qajar king did not pay much attention to the proposal. However, with the establishment of constitutional rule in the country, the idea of setting up a national Iranian bank in order to reduce political and economic influence of foreigners gained strength and at last in December 1906 the establishment of the bank was announced and its articles of association compiled.

In April 1927, the Iranian Parliament gave final approval to the law allowing the establishment of Bank Melli of Iran. But, due to some problems the Cabinet ministers and the parliament's financial commission approved the articles of association of the bank in the spring of 1928. The Central Bank of Iran was established in 1928, tasked with trade activities and other operations (acting as the treasurer of the government, printing bank notes, enforcing monetary and financial policies and so on). The duties of the CBI included making transactions on behalf of the government, controlling trade banks, determining supply of money, foreign exchange protective measures and so on.

In June 1979, Iranian banks were nationalized and banking regulations changed with the approval of the Islamic banking law (interest free), and the role of banks in accelerating trade deals, rendering services to clients, collecting deposits, offering credits to applicants on the basis of the CBI's policies and so on was strengthened. In short now days there are currently around seventeen commercial banks in Iran, of which eleven are state-owned and six are privately owned which all the banks must follow Islamic banking principles whereby usury is forbidden and, rather than AIRs, profit rates are set on deposits and expected rates of profit on facilities are set on loans. In terms of both assets and capital, the banking sector is dominated by Bank Melli Iran (National Bank of Iran). In recent years, six privately owned banks, Bank Kafarin, Bank Parsian, Bank Eqtesad-e-Novin Bank Saman, Bank Pasargad and Bank Sarmaye have commenced operations in Iran for the first time since the nationalization of the Iranian banking sector in 1952.

\section{Review of literature}

Costs of transactions in e-banking can be as low as a tenth of the cost of banking through conventional means. A further very telling factor is that Internet banking clients generate twice the revenue of a bank's traditional customers and we already know that the cost of their transactions is one-tenth of the cost of transactions through conventional banking; and access to e-banking is becoming easier all the time.

Banking industry, locally as much as internationally, is becoming a tougher business to run and grow, given the increasing competition in a shrinking globe. Bankers are looking more and more into solutions to better reach out to their customers, improve customer's loyalty, gain competitive advantage, and provide better services, while reducing their running cost and generating more revenues.

Daniel (1999) described e-banking as the provision of banking services to customers through new technology. Other researches (Daniel, 1999; Karjaluoto et al., 2002) indicated that banks have the choice to offer their banking services through various electronic distribution channels technologies such as Internet technology, video banking technology, telephone banking technology, and WAP technology. Karjaluoto et al. (2002) also indicated that Internet technology is the main electronic distribution channel in the banking industry. In other words, e-banking as an online banking that involves the provision of banking services such as accessing accounts, transferring funds between accounts, and offering an online financial service.

Wang et al. (2003) claim that in the 1990s e-banking was under-utilised as business organisations used it only to market their products and services. Thornton and White (2001), who examined customer orientations and usage of financial distribution channels in the Australian financial industry, found that more recently most financial institutions, faced with competitive pressure after the introduction of deregulation in 1983, have rethought their strategies to take full advantage of Internet technology. Tan and Teo (2000) note that the challenge to expand and maintain banking market share has influenced many banks to invest more in making better use of the Internet. The emergence of e-banking had made many banks rethink their Information Technology (IT) strategies in competitive markets.

They suggest that the banks that fail to respond to the emergence of e-banking in the market are likely to lose customers and that the cost of offering e-banking services is less than the cost of keeping branch banking. This notion was also confirmed in a study conducted by Jasimuddin (2004) who examined the role of e-banking in Saudi Arabia. He indicated that the majority of Saudi banks had taken advantage of Internet technology to establish web sites but few offered e-banking services. He suggested that if the Saudi Arabian banking industry wished to be successful in the global economy it would need to integrate Internet technology into its banking strategy.

Chiemeke et al. (2006) conducted an empirical investigation on adoption of e-banking in Nigeria. The study identified the major inhibiting factors to Internet banking adoption in Nigeria such as, insecurity, inadequate operational facilities including telecommunications facilities and electricity supply, and made recommendations on how Nigeria banks can narrow the digital divide. Also, the report revealed that Internet banking is being offered at the basic level of interactivity with most of the banks having mainly information sites and providing little Internet transactional services. 
Similarly, Agboola (2006) investigated electronic payment systems and tele-banking services in Nigeria. The findings revealed that there has been a very modest move away from cash. Payments are now being automated and absolute volumes of cash transactions have declined. The result of the study revealed that tele-banking is capable of broadening the customer relationship, retain customer's loyalty and enable banks to gain commanding height of market share if their attendant problems such as, ineffectiveness of telecommunications services, epileptic supply of power, high cost, fear of fraudulent practices and lack of facilities necessary for their operation were taken care of.

Ayo (2006) investigated the prospects of e-commerce based on ability, motivation and opportunities (AMO) model and observed that virtually all companies have online presence. The paper reported the motivation and opportunities for e-commerce as low based on lack of e-Payment infrastructure and access to ICT facilities.

Also, in an empirical assessment of customer acceptance of m-Commerce carried out in Germany, and reported by Buse and Tiwari (2006) as follows:

1) The highest mobile users are top management, followed by self employed, salaried class, students and others. Government employees were found not to patronize mobile banking.

2) The most favored reason for carrying out mobile banking is ubiquity, next is overview of bank account, followed by immediacy.

3) The highest fear of customers about mobile banking is that of insecurity, next is cost, and uncomfortably.

\section{Research questions and hypotheses}

According to the above literature e-banking caused so many advantages, so the research questions are as below:

Q1: does e-banking cause advantages to Iranian banks?

Q2: are there some barriers for using e-banking in Iran?

According to the above research questions the hypotheses of the study as follow:

H1: from the view points of customers, e-banking cause higher advantages to Iran;

H2: e-banking leads to increase of volume of transactions in Iran;

H3: e-banking leads to increase in using ATM among the banks' customers in Iran; and

H4: non-existing of enough knowledge have led to decrease in using e-banking in Iran.

\section{Research Methodology}

Two research tools were employed. The first is an exploratory research based on secondary data obtained through the Net, books and related journals.

Secondly, Survey questionnaire was administered to empirically assess the level of adoption of e-banking in Iran. A survey questionnaire was completed by the banks customers, at the end of 2008. The questionnaire contains two parts namely (A) bio-data and (B) this section includes several questions regarding to the e-banking services which rendering in Iran. Five-Point Likert Scale questionnaire was employed in this research. The Five-Point Likert's scale having the ratings of "strongly disagree" (1) and "strongly agree" (5) were used. For analyzing data X2 is employed which is the most relevant test to this kind of study.

A total of eight hundred (800) questionnaires were randomly administered to business men and customers in the general public. Six hundred (600) were returned, which represents $75 \%$ of the total respondents. The bio data of participants is summarized in Table. 1

Insert Table 1 Here

As Table 1 shows, out of 600 participants 325 (54.17\%) are female and 275 are male. It means that the majority of participants are female. Majority of the respondents were between ages 31 to 50 years, which represent $51.5 \%$ followed by ages 41 to 50 years with $16.50 \%$. Regarding to educational background, out of 600 respondents 281 had bachelor degree which represent $46.83 \%$ followed by master degree of 201 participants in percentage $33.50 \%$. The least number of participants had $\mathrm{PhD}$ degree (1.17\%).

Related to job position, majority of the respondents were clerk, which represent $34.50 \%$ followed by Businessman with $20.33 \%$. Out of 600 participants 189 were self employed in percentage $31.50 \%$. The least number of participants fall in the category of others (teacher, student and housewife).

\section{Analysis and interpretation of data}

In order to analyzing data, as it is mentioned before, $\mathrm{X} 2$ test is employed. The results of testing hypotheses is summarized in Table. 2

The first hypothesis postulated in this study is: 
H1: from the view points of customers, e-banking cause higher advantages to Iran.

According to table 2 the first hypothesis is accepted and null hypothesis is rejected. In other words, Iranian banks enjoy highly from e-banking in Iran. In this condition Jayawardhena and Foley (2000) explore the e-banking as a new delivery channel arguing that e-banking may help to overcome the inherent disadvantages of traditional banks.

Insert Table 2 Here

The second hypothesis is:

H2: e-banking leads to increase of volume of transactions in Iran.

Table 2 shows that this hypothesis is also accepted and a null hypothesis is rejected.

It is very clear that if e-banking conducted successfully it leads to big volume of transactions, further Birch and Young (1997) argue that the internet may be exploited as a new delivery channel by the financial services industry to completely reorganize the structure of banks.

The third hypothesis is:

H3: e-banking leads to increase in using ATM among the banks' customers in Iran.

With reference to table 2 this hypothesis also accepted. It means that conducting e-banking in Iran leads more usage of ATM in Iran. The authors came to conclusion that the active ATM in banking sectors will cause cash circulation decreases, the efficiency of banking sector will increase, as:

a. client banking costs decreases (less cash fees to pay),

b. shop keeper / service provider costs will decrease, and

c. bank costs decrease (cash storage, less checking and processing costs)

The fourth hypothesis is:

H4: non-existing of enough knowledge have led to decrease in using e-banking in Iran.

With regard to table 2 the results of this study show that this hypothesis is also accepted, in other words, the Iranian costumers have not enough knowledge related to e-banking in Iran. Accordingly the null hypothesis is rejected also. The authors believe that the lack of enough information on e-banking in Iran may cause less efficiency of Iranian banks.

To achieving high efficiency both bankers as well as Iranian legislators should introduce e-banking services at mass level. By the way, improving society knowledge through out TV, bulletin, etc will improve the knowledge of society at whole.

\section{Conclusion}

A strong banking industry is important in every country and can have a significant affect in supporting economic development through efficient financial services (Salehi and Azary, 2008, Salehi et al. 2008). Iranian banks have rapidly introduced innovative banking technologies and e-banking services in recent years. Almost all banks have invested in expanding and improving the IT systems and a number of new e-banking services have been developed.

All major banks have declared e-business as one of the core strategies for the future developments. At the same time, e-banking acceptance depends probably on bank service quality, customer preferences and satisfaction. One of the main reasons for the growth of e-banking is that, if handled correctly, it can significantly lower the cost of delivering products and services. The results of this study showed that the customers also strongly agree with e-banking in Iran.

However, with banking customers growing increasingly comfortable with the digital lifestyle, their expectations from financial service providers have undergone a significant transformation but Iranian customers are not aware about e-banking in Iran. They are not fully understand the power of technology and seek to leverage it to enjoy better control over their banking operations. According to this condition we are at on the middle of the way. Bankers and practitioners should try to introduce e-banking very well in Iran. To conclude that e-banking may also provide other benefits. For instance, creating new markets, and reducing operational costs, administrative costs and workforce are increasingly important aspects for the banks' competitiveness, and e-banking may improve these aspects as well. So, Iranian banks should take these advantages of e-banking in Iranian economics as early as possible.

\section{References}

Aarma, August; Vensel, Vello. (2001). Banks' Retail Customer Satisfaction and Development of Bank-Customer relationships, in Vello Vensel; Clas Wihlborg, eds. Estonia on the Threshold of the European Union: Financial Sector and Enterprise Restructuring in the Changing Economic Environment, Tallinn: Tallinn Technical University, 2001, pp. 85-106. 
Agboola A. A. (2006). Electronic Payment Systems and Tele-banking Services in Nigeria, Journal of Internet Banking and Commerce, December 2006, vol. 11, no.3 (http://www.arraydev.com/commerce/jibc/)

Aladwani, Adel. (2001). Online Banking: A Field Study of Drivers, Development Challenges, and Expectations, International Journal of Information Management, 21, pp. 213-225.

Aladwani, Adel. (2001). Online Banking: A Field Study of Drivers, Development Challenges, and Expectations," International Journal of Information Management, 21, pp. 213-225.

Ayo Charles K. (2006). The Prospects of e-Commerce Implementation in Nigeria, Journal of Internet Banking and Commerce, December 2006, vol. 11, no.3 (http://www.arraydev.com/commerce/jibc/)

BankAway (2001). Net Banking Benefits! Sheer Acceleration, Electronic Banking: The Ultimate Guide to Business and Technology of Online Banking, Edited by SCN Education B.V.

Basel Committee Report on Banking Supervision. (1998). Risk management for electronic banking and electronic money activities, Switzerland: Bank of International Settlements

Birch D., M. Young. (1997). Financial services and the internet-what does the cyberspace mean for the financial services industry? Internet Research: Electronic Networking Applications and Policy, vol.7, n.2, pp. 120-128.

Burr, W. (1996). Wie Informationstechnik die Bankorganisation verändern könnte,” Bank und Market, 11, pp. 28-31.

Buse S., R. Tiwari. (2006). Mobile Banking stages a remarkable come back, Press Release, [Online], Retrieved Feb, 2007 http://wwwl.uni-hamburg.de/m-commerce/banking/index_e.html.

Chiemeke S. C., A. Evwiekpaefe and F. Chete. (2006). The Adoption of Internet Banking in Nigeria: An Empirical Investigation, Journal of Internet Banking and Commerce, December 2006, vol. 11, No.3 (http://www.arraydev.com/commerce/jibc/)

Daniel, E. (1999). Provision of electronic banking in the UK and the Republic of Ireland, International Journal of Bank Marketing, 17, 2, , pp. 72-82.

Gurău, Catalin. (2002). E-banking in Transition Economies: the Case of Romania, Journal of Financial Services Marketing, 6, 4, pp. 362-379.

Jasimuddin, S. (2004). Saudi Arabia Banks on the Web, Retrieved 15 November 2004, from www.arraydev.com/commerce/jibc/0103-02.htm.

Jayawardhena C., P. Foley. (2000). Changes in the banking sector-the case of internet banking in the UK, Internet Research: Electronic Networking Applications and Policy, vol.10, N.1, pp. 19-30.

Karjaluoto, Heikki; Mattila, Minna; Pento, Tapio. (2002). Electronic Banking in Finland: Consumer Beliefs and Reactions to a New Delivery Channel, Journal of Financial Services Marketing, 6, 4, , pp. 346-361.

La Porta, R., F., Lopez-de-Silanes and Shleifer. A. (2002). Government Ownership of Banks, Journal of Finance, Vol. 57, No. 1, pp: 256-301.

Mayer, C. (1990). Financial Systems, Corporate Finance, and Economic Development, In: Hubbard, R.G. (Ed.), Asymmetric Information, Corporate Finance and Investment. University of Chicago Press, Chicago, pp. 307-332.

Mols, Niels. (1998). The Behavioral Consequences of PC banking, International Journal of Bank Marketing, 16, 5, , pp. 195-201.

Nathan, L. (1999). Www.your-community-bank.com: community banks are going online, Community and Banking, Federal Reserve Bank of Boston.

Pohjola, Matti. (2002). The New Economy: Facts, Impacts and Policies, Information Economics and Policy, 14, pp. 133-144.

Pyun, Chong Soo; L. Scruggs, N. Nam. (2002). Internet banking in the US, Japan and Europe, Multinational Business Review, fall, pp. 73-81.

Salehi, Mahdi and Zhila Azary. (2008). Fraud Detection and Audit Expectation Gap: Empirical Evidence from Iranian Bankers, International Journal of Business and Management, Vol. 3, No. 10, pp. 65-77.

Salehi, Mahdi, Ali Mansouri and Zhila Azary. (2008). Islamic Banking Practice and Satisfaction: Empirical Evidence from Iran, ACRM Journal of Business and Management Research, Vol. 3, No.2, pp. 35-41.

Sathye, Milind. (1999). Adoption of Internet Banking by Australian Consumers: An Empirical Investigation, International Journal of Bank Marketing, 17, 7, , pp. 324-334.

Simpson, J. (2002). The impact of the Internet in banking: Observations and evidence from developed and emerging markets, Telematics and Informatics, Vol. 19. No. 4, 315-330. 
Tan, M. and T. Teo. (2000). Factors Influencing the Adoption of Internet Banking, Journal of the Association for Information Systems 1(5): 1-42.

Thornton, J. and L. White. (2001). Customer Orientation and Usage of Financial Distribution Channels, Journal of Services Marketing 15(3): 168-185.

Wang, Y.S., Y.M. Wang, H.H. Lin, and T.I. Tang. (2003). Determinants of User Acceptance of Internet Banking: an Empirical Study, International Journal of Service Industry Management, Vol. 14 No. 5, pp. 501-19.

Table 1. Bio data of participants

\begin{tabular}{|l|l|l|l|}
\hline Variable & Category & Frequency & Percentage \\
\hline \multirow{4}{*}{ Gender } & Male & 275 & 45.83 \\
\cline { 2 - 4 } & Female & 325 & 54.17 \\
\hline \multirow{5}{*}{ Age } & $20-30$ & 98 & 16.34 \\
\cline { 2 - 4 } & $31-40$ & 309 & 51.50 \\
\cline { 2 - 4 } & $41-50$ & 99 & 16.50 \\
\cline { 2 - 4 } & 50 and upper & 94 & 15.66 \\
\hline \multirow{5}{*}{ Job position } & Diploma & 111 & 18.50 \\
\cline { 2 - 4 } & B.S & 281 & 46.83 \\
\cline { 2 - 4 } & M.S/M.A & 201 & 33.50 \\
\cline { 2 - 4 } & PhD & 7 & 1.17 \\
\hline & Businessman & 122 & 20.33 \\
\cline { 2 - 4 } & Clerk & 207 & 34.50 \\
\cline { 2 - 4 } & Self employed & 189 & 31.50 \\
\cline { 2 - 4 } & Others & 82 & 13.67 \\
\hline
\end{tabular}

Table 2. The results of testing hypotheses

\begin{tabular}{|l|l|l|l|l|l|}
\hline Hypotheses & X2 Table amount & Mono-sample X2 amount & D.f & Alpha P-value & Results \\
\hline Hyp. No. 1 & 7.814 & 8.162 & 3 & 0.043 & Accepted \\
\hline Hyp. No. 2 & 5.991 & 17.10 & 2 & 0.002 & Accepted \\
\hline Hyp. No. 3 & 3.841 & 6.00 & 1 & 0.014 & Accepted \\
\hline Hyp. No. 4 & 6.002 & 18.08 & 3 & 0.001 & Accepted \\
\hline
\end{tabular}

